\title{
TEORI BELAJAR AL-MĀWARDI: \\ STUDI ANALISIS TUJUAN DAN INDIKATOR \\ KEBERHASILAN BELAJAR
}

\author{
Nurhayati AR \\ Jurusan Tarbiyah STAIN Malikussaleh Lhokseumawe \\ Email: nurhayati.p2m@gmail.com)
}

Syahrizal

(Program Doktoral USM Pulau Penang, Malaysia)

Abstract: Al-Māwardi's concept of learning goals and indicators have rarely been studied and developed in the context of modern education. This article examines the learning goals and indicators of successful education in the thoughts of al-Māwardi and analyzes its relevance to modern education. According to al-Mawardi, successful education can be achieved when students can memorize, understand, know the purpose of learning and practice what they have learnt, and when these indicators shape students' cognitive, affective, and psychomotor domains. He maintained that these learning processes must be based on a sound faith. This article demonstrates that these objectives and indicators of successful learning proposed by alMawardi are very relevant to modern education. Faith based education helps increase student's belief and discards worldly-oriented education that tend to produce materialistically individualistic people.

Abstrak: Teori belajar al-Māwardi tentang tujuan dan indikator keberhasilan belajar belum dikaji dan dikembangkan dalam konteks pendidikan modern. Tulisan ini bertujuan mendeskripsikan tujuan dan indikator keberhasilan belajar menurut al-Mäwardi dan menganalisis relevansinya dalam pelaksanaan pendidikan modern. Indikator keberbasilan belajar anak didik menurut al-Mäwardi mencakup menghafal, memahami, mengetabui tujuan belajar, dan mengamalkan ilmu; semua itu menyentuh ranah kognitif, afektif, dan psikomotorik yang terintegrasi ke dalam ranah iman. Pandangan itu sangat relevan untuk diaplikasikan dalam konteks pendidikan modern untuk. membangun pribadi muslim yang ikhlas karena Allah dalam menjalankan segala aktivitasnya, dan memiliki keseimbangan antara tujuan duniawi dengan ukhrawi.

Keywords: teori belajar, tujuan belajar, indikator keberhasilan belajar. 
BELAJAR merupakan salah satu aktivitas manusia yang penting dan tidak dapat dipisahkan dari kehidupan manusia, bahkan sejak mereka lahir sampai akhir hayat. Belajar yang efektif harus ditopang oleh teori belajar yang efektif pula, diantara teori belajar yang tidak asing lagi di lingkungan pendidikan adalah teori belajar yang berasal dari dunia pendidikan Barat diantaranya teori belajar behavioristik, yang dikembangkan oleh Pavlov. Skinner, Thorndike; teori belajar kognitivistik yang dikembangkan oleh Piaget, Brunner, Ausabel; teori belajar humanistik yang dikembangkan oleh Abraham Maslow, Combs; teori belajar sibernetik yang dikembangkan oleh Landa, Pask dan Scott; teori belajar sosial learning yang dikembangkan oleh Albert Bandura dan banyak lagi teori-teori belajar yang lain.

Harus diketahui bahwa teori belajar tidak hanya dikemukakan oleh tokoh-tokoh pendidikan Barat, tetapi jauh sebelumnya para tokoh pendidikan Islam, baik yang hidup di era klasik, pertengahan, maupun yang hidup di era modern, telah membahas tentang belajar dan pembelajaran dalam karyanya masingmasing. Tetapi gagasan mereka tentang teori belajar secara umum masih kurang mendapat perhatian dari kita (umat Islam), terutama pihak-pihak yang bergelut dalam dunia pendidikan.

Al-Māwardi adalah seorang ulama dan tokoh pendidikan Islam klasik yang banyak memberikan kontribusi pemikiran terhadap kemajuan pendidikan Islam. Di antara kontribusi pemikirannya adalah teori tentang belajar. Teori belajar AlMāwardi-meskipun lahir lebih kurang 11 abad yang lalusecara umum masih bisa dikatakan tidak/belum ada pengembangannya dalam pendidikan modern. Teori belajar alMāwardi hanya termaktub dalam kitab Adāb al-Dunyà wa al-Din. Tidak ada yang berusaha mengkajinya dalam bentuk penelitianpenelitian atau karya tulis ilmiah lainnya. Padahal kalau ditelaah lebih jauh, teori belajar al-Mawardi tersebut sangat penting diketahui, dikaji, bahkan kemungkinan untuk diaplikasikan dalam pendidikan Islam modern.

Yang menarik dalam kajian ini adalah bahwa al-Māwardi baik di dunia Islam maupun dunia Barat lebih dikenal sebagai tokoh atau bapak politik dunia. Ini dikarenakan al-Māwardi banyak menulis tentang politik dan juga mayoritas peneliti 
mengkaji pemikiran al-Māwardi tentang politik atau ketatanegaraan. Sebenarnya al-Māwardi tidak hanya ahli di bidang politik tetapi juga pakar dalam bidang pendidikan Islam sehingga dapat dikatakan sebagai tokoh pendidikan Islam. Inilah yang belum banyak dikaji dan diketahui bahwa sesungguhnya alMāwardi juga seorang pakar pendidikan. Oleh karena itu peneliti tertarik untuk mengkaji lebih lanjut dan mendalam tentang pemikiran al-Māwardi dalam pendidikan. Tulisan ini bertujuan mendeskripsikan teori belajar menurut al-Māwardi khususnya tentang tujuan dan indikator keberhasilan belajar dan menganalisis relevansi tujuan dan indikator keberhasilan belajar menurut al-Māwardi dalam pelaksanaan pendidikan Islam dewasa ini.

\section{Sketsa Biografi al-Māwardi}

Nama lengkapnya adalah Abū al-Hasan 'Ali bin Muhammad bin Habīb al-Bashriy al-Māwardiy. ${ }^{1}$ Dari nisbah namanya "alBashriy" dapat diketahui bahwa ia berasal dari Bashrah, salah satu negeri dalam wilayah Baghdād. Sementara "al-Māwardiy" adalah nama laqabnya yang dinisbahkan kepada bai' mä' al-ward, artinya menjual air bunga mawar. Dijuluki al-Mâwardi karena ia berasal dari salah satu keluarga Arab yang membuat dan memperdagangkan air mawar. ${ }^{3}$ Ia lahir di Bashrah pada tahun $364 \mathrm{H}$ bertepatan dengan tahun $974 \mathrm{M} .{ }^{4}$ Abad IV H/ abad X M berdasarkan klasifikasi sejarah Islam menurut Harun Nasution ${ }^{5}$

${ }^{1} \mathrm{Abu}$ al-Hasan 'Āli bin Muhammad bin Habīb al-Basriy al-Māwardiy, Adāb al-Dunyà wa al-Dìn, Tab'ah Jadīdah Munaqqahah Musahhahah, Ishraf Maktab al-Buhūth wa al-Dirāsat, (Bayrūt-Libnan: Dār al-Fikr li al-Tabāah wa al-Nashr wa al-Tauzì', 1415 H/1995 M), 4.

2Sa'īd Ismā̄îl al-Qādi, Usūl al-Tarbiyah al-Islāmiyyah, al-Tab'ah al-Ulā, (alQāhirah: 'Alām al-Kutub, 1422/2002), 232.

3Jamil Ahmad, Seratus Muslim Terkemuka, Penerjemah Tim Penerjemah Pustaka Firdaus, Cetakan Keenam, (Jakarta: Pustaka Firdaus, 1996), 163.

4al-Māwardiy, Adāb..., 4; al-Qādi, Usūl.., 232; Abuddin Nata, Pemikiran Para Tokoh Pendidikan Islam; Seri Kajian Filsafat Pendidikan Islam (Jakarta: RajaGrafindo Persada, 2001), 43.

${ }^{5}$ Harun Nasution mengklasifikasikan sejarah Islam kepada 3 kelompok besar, yaitu era klasik (650-1250 M), era pertengahan (1250-1800 M), dan era modern (1800 M dan seterusnya). Lihat, Harun Nasution, Pembaharuan dalam Islam Sejarah Pemikiran dan Gerakan (Jakarta: Bulan Bintang, 1992), 12-4. 
adalah era klasik atau era keemasan Islam. Ini menunjukkan bahwa al-Māwardi hidup pada era klasik atau era keemasan Islam tersebut. Dengan demikian, pola pemikiran al-Māwardi sangat dipengaruhi dan tidak terlepas oleh kondisi dimana ia hidup.

Al-Māwardi memulai pendidikan di tanah kelahirannya, Basrah. Hadis dipelajarinya dari beberapa ulama terkenal seperti al-Hasan bin 'Āli bin Muhammad al-Jabaliy al-Muhaddith, Muhammad bin 'Adiy bin Zuhar al-Maqri', Muhammad bin alMa'āliy al-Azdiy, dan Ja'far bin Muhammad bin al-Fadl alBagdādiy. Selain hadits, Ia juga belajar fiqh dari ulama-ulama terkenal lainnya, seperti Abū al-Qāsim 'Abd al-Wāhid bin Muhammad al-Shaimiriy, hakim di Basrah, dan Abū Hāmid Ahmad bin Abi Tahir al-Isfarayaniy di Baghdad. ${ }^{6}$ Ilmu-ilmu lain juga dipelajari al-Māwardi, seperti sastra, nahwu, filsafat, dan sebagainya, tapi tidak dijumpai informasi dari siapa ia berguru ilmu-ilmu tersebut.

Setelah merasa mampu menguasai berbagai macam disiplin ilmu, lalu al-Māwardi mengadakan majlis ilmiah sendiri. Di majlis tersebut, ia mengajar ushul dan kaedah-kaedah fiqh, politik dan tata caranya, khilafah dan kewajibannya, dan hal-hal yang berkaitan dengan kementerian, perwilayahan, dan perkantoran. ${ }^{7}$ Majlis ilmiahnya banyak didatangi oleh pelajar yang kemudian hari menjadi ulama-ulama terkenal, seperti alMaqdisiy, al-Khatīb al-Bagdādi, Ibnu al-Baqqālani, Ibnu Qadisy al-'Akbariy, Ibnu Arābiyah, Abū Hasan al-Abdari, dan lain-lain. ${ }^{8}$

Selain mengajar, al-Māwardi sebagai salah seorang faqūh mazhab Shāfíīe, juga menduduki posisi penting dalam pemerintahan pada saat itu, yaitu menjabat sebagai hakim di beberapa kota, seperti di Uthuwa (Iran) dan di Baghdād. ${ }^{?}$

Gal-Māwardiy, Adāb..., 4.

7al-Qādi, Usüul.., 233.

${ }^{8}$ Ibid. Informasi ini dikutip oleh Sā̄id Ismāîil al-Qādi dari Ibn Kathīr, alBidāyah wa al-Nihāyah, jilid 12, (al-Qāhirah: Dār al-Fikr al-'Arabi, dūna alsanah), 80; Khayr al-Dīn al-Zarkali, al-A'làm, juz 4, (Beirūt: Dār al-Ilm li alMalāyīn, 1992), 327, dan al-Sam'āni, al-Ansab, juz 5, taqdīm wa ta'līq 'Abd Allah 'Umar al-Barudi, (Bayrūt: Dār al-Jinan, 1408 H/1988 M), 182.

${ }^{9}$ Mircea Eliade, The Encyclopedia of Religion, vol. 9 (New York: Macmillan Publishing Company, t.t.), 290. 
Selanjutnya pada era khalifah al-Qāim bin Amr al-Lāh al'Abbāsi, ia ditugaskan sebagai duta diplomatik untuk melakukan negosiasi dalam menyelesaikan berbagai persoalan dengan para tokoh pemimpin dari kalangan Bani Buwaihi Seljuk Iran. ${ }^{10}$ Dengan keahlian, kepiawaian, dan keberhasilannya, ia mendapat gelar Aqda al-Qudāh (Hakim Agung). ${ }^{11}$

Sebagai seorang ulama terkenal, selain sibuk mengajar dan meniti karir dalam pemerintahan, ia sempat meluangkan waktu untuk menulis karya ilmiah. Sebagai seorang penulis produktif, ia telah menghasilkan 12 karya. Abuddin Nata mengklasifikasikan 12 karya al-Māwardi tersebut ke dalam tiga kelompok ilmu pengetahuan, yaitu kelompok ilmu pengetahuan agama, kelompok ilmu pengetahuan tentang politik dan ketatanegaraan, dan kelompok ilmu pengetahuan tentang akhlak. ${ }^{12}$ Yang termasuk ke dalam kelompok ilmu pengetahuan agama adalah Kitab Tafsìr, Kitab al-Häwiy al-Kabìr, Kitab al-Iqnä' (ringkasan kitab al-Hāwiy, Kitab Adāb al-Qādiy dan Kitab A'làm alNubumwah. Karya-karyanya yang termasuk ke dalam kelompok ilmu pengetahuan tentang politik dan ketatanegaraan adalah alAbkäm al-Sultaniyah, Kitab Nasībah al-Mulk, Kitab Qawānin alWazärah wa Siyāsah al-Mulk, dan Kitab Tasil al-Nazar wa Tajjil alZafar. Dan yang termasuk ke dalam kelompok ilmu pengetahuan tentang akhlaq adalah Kitab fi al-Nabwi, Kitab al-Amtäl wa alHikeam, Kitab al-Bughyah al-Ulya fì Adāb al-Dunyà wa al-Din atau terkenal dengan Adāb al-Dunyã wa al-Din.

Karya-karya tersebut menunjukkan bahwa al-Māwardi adalah seorang ilmuwan yang menguasai berbagai disiplin ilmu. Dengan demikian, al-Māwardi dapat dikatakan sebagai seorang faqih, politikus, mufassir, hakim, penulis biografi, ahli debat, ahli nahwu, ahli hikmah, dan moralis.

Melalui berbagai karyanya itulah, al-Māwardi menyampaikan ide-ide dan teori-teorinya sehingga banyak tokoh dan para ulama

${ }^{10}$ Yaqūt al-Harmany, Mu'jam al-Udabā', jilid xv, (Dār al-Ihyā' al-Turāth al-'Arabi, t.t.), 54.

11al-Zarkali, al-A'làm, 327.

${ }^{12 N a t a, ~ P e m i k i r a n . . ., ~ 47-8 . ~}$ 
setelahnya bahkan para ahli masa sekarang mengutip dan mengadopsi pemikiran-pemikiran dan teori-teorinya itu. ${ }^{13}$

Al-Māwardi wafat di Baghdād pada hari Selasa akhir bulan Rabiul Awal tahun $450 \mathrm{H} / 1058 \mathrm{M}$ dalam usia 86 tahun menurut hitungan tahun hijriyah. Ia dikuburkan pada hari Rabu di pekuburan Bab Harb. ${ }^{14}$

\section{Deskripsi Teori al-Māwardi tentang Tujuan Belajar}

Rumusan tujuan belajar yang dikemukakan al-Māwardi dapat dipahami dari penjelasannya dalam kitab Adāb al-Dunyā wa alDìn, bab kedua; Adāb al-Ilmi. Tujuan belajar menurut al-Māwardi dapat diklasifikasikan kepada dua, yaitu tujuan yang baik (positif) dan tujuan yang jelek (negatif).

\section{Tujuan belajar yang baik (positif)}

Al-Māwardi memformulasikan tujuan yang baik (positif) menjadi dua, yaitu; pertama, qāsidan wajh al-Lah ta'ālā (niat karena Allah Swt.). Dalam memformulasikan tujuan belajar tersebut alMāwardi berpijak atau merujuk kepada hadits, artinya: "Barangsiapa yang mempelajari ilmu karena selain Allah Swt. dan dengan ilmu ia menginginkan selain Allah Swt., maka hendaklah menempati tempat duduknya dari neraka." Alasan logisnya adalah bila belajar karena mencari ridha Allah Swt., maka apa yang dipelajari itu akan baik dan bermanfaat. Tentu saja tidak hanya baik dan bermanfaat bagi anak didik itu sendiri tapi juga bermanfaat bagi orang lain di dunia maupun di akhirat. Apa yang dipelajari itu akan menjadi baik dan bermanfaat jika yang dipelajari itu diamalkan oleh anak didik itu sendiri dalam kehidupan sehari-hari. Jika tidak diamalkan, hasilnya nihil, seperti pohon yang tidak berbuah.

Kedua, wäthiqan bi taisì al-Lah bi niyyat al-khälisah wa 'azimah sädiqah (mencari kemudahan dari Allah Swt. dengan niat suci dan cita-cita yang mulia). Belajar dengan niat suci kepada Allah Swt. dan cita-cita mulia akan membawa dampak yang sangat positif bagi anak didik, karena belajar tidak akan mencapai keberhasilan

${ }^{13}$ Abuddin Nata, Sejarah Sosial Intelektual Islam dan Institusi Pendidikannya (Jakarta: RajaGrafindo Persada, 2012), 76.

14al-Māwardiy, Adāb..., 5; al-Qādi, Usūl.., 234. 
yang sempurna tanpa dikaitkan dengan dimensi ketauhidan. Tujuan belajar yang berdimensi ketauhidan adalah tujuan belajar yang mengarah kepada tujuan akhir dari suatu proses pendidikan.

\section{Tujuan belajar yang jelek (negatif)}

Tujuan belajar yang jelek (negatif) diformulasikan alMāwardi kepada tiga hal, yaitu; pertama, tujuan belajar karena riya (Ta'allum li al-riya $\bar{a}$ ). Riya dalam istilah agama diartikan sama dengan sombong. ${ }^{15}$ Menurut al-Ghazāli di dalam Arba'in fì Usül al-Din sebagaimana dikutip al-Palimbani menjelaskan bahwa hakikat riya adalah "mencari kedudukan dan kemegahan dalam hati manusia dengan cara melebihkan ibadah dan memperlihatkan amal kebajikan kepada manusia dengan tujuan untuk dipuji, dimuliakan, mendapat kemegahan, harta, dan sebagainya dari kesukaan dan kemegahan dunia."16

Dari pengertian di atas menunjukkan bahwa karakteristik riya itu adalah melakukan sesuatu untuk mencari kedudukan di kalangan manusia, memperlihatkan kebaikan untuk dipuji oleh orang lain, dan sebagainya. Riya bersumber dari enam aspek, yaitu riya dari aspek jasmani, ${ }^{17}$ riya dengan kelakuan, ${ }^{18}$ riya dari

15Kamisa, Kamus Lengkap Bahasa Indonesia Dilengkapi: Ejaan Yang Disempurnakan dan Kosa Kata Baru (Surabaya: Kartika, 2997), 450.

${ }_{16}{ }^{\circ} \mathrm{Abd}$ al-Samad al-Palimbani, Siyar al-Sälikin fi Tariqah al-Sadat alSufiyah, juz 3-4, (Indonesia: Dār al-Kutub al-'Arabiyah, t.t.), 147-8.

${ }^{17}$ Riya dari aspek jasmani seperti: 1). Menampakkan badan kurus dan kuning muka kepada orang agar ia disangka orang yang banyak puasa dan berjaga pada malam hari untuk beribadah, 2). Menampakkan kecitaan kepada manusia agar disangka himmah di dalam agama, 3). Menampakkan rambut kusut dan badan berdebu kepada orang agar ia dikatakan oleh orang sebagai orang shalih dan antusias berbuat demi agama sehingga tidak menghiraukan dirinya sendiri, 4). Menampakkan dua bibir yang kering agar disangka orang ia itu berpuasa dan menampakkan suara kecil agar ia disangka orang sebagai orang lemah karena rajin beribadah, dan sebagainya.

${ }^{18}$ Riya dengan kelakuan seperti: Mencukur kumis, menundukkan kepala saat berjalan, menetapkan perjalanan, meninggalkan bekas sujud di muka, dan memejamkan kedua mata. Semua itu dilakukan agar disangka orang ia terus-menerus dalam sujud kepada Allah Swt., dan juga agar disangka orang ia terus- menerus di dalam ilmu mukasyafah karena memikirkan Tuhannya. 
aspek pakaian, ${ }^{19}$ riya dari aspek lisan, ${ }^{20}$ riya pada aspek asal amal, ${ }^{21}$ dan riya dari aspek membanyakkan murid dan sahabat yang mengikutinya. ${ }^{22}$ Keenam sumber riya tersebut adalah dosa besar.

Kedua, dipuji oleh orang-orang bodoh (Tumüri al-Sufahāa). Tujuan belajar untuk dipuji oleh orang-orang bodoh juga termasuk perbuatan riya. Dan ini sangat dilarang dalam agama karena sudah melenceng dari aturan agama itu sendiri. AlMāwardi melarang anak didik belajar untuk dipuji oleh orangorang bodoh. Agama melarang yang demikian karena akan melahirkan sifat sombong pada diri anak didik.

Ketiga, berdebat dengan para ulama (mujädalab al-ulamā'). Dalam menguatkan penjelasan tentang tujuan belajar yang jelek (negatif) pada poin 2 dan 3 di atas, al-Māwardi berpijak kepada hadits, artinya: "Janganlah kalian mempelajari ilmu dengan tujuan berdebat dengan orang-orang bodoh dan untuk berdebat

${ }^{19}$ Riya dari aspek pakaian, seperti: 1). Memakai kain sufi, memakai pakaian yang kasar-kasar, memakai baju pendek sampai setengah betis, memakai baju pendek sampai ke pergelangan tangan, memakai kain lusuh agar disangka orang ia itu orang zuhud dan wara', memakai kain yang bertambal-tambal, memakai kain tempat sujud agar disangka ia itu orang sufi, 2). Memakai pakaian seperti pakaian ulama supaya orang menyangkanya orang alim, dan sebagainya.

20Riya dari aspek lisan seperti: 1). Membaguskan ucapan dengan pengajaran, penjagaan, berbicara dengan ilmu hikmah, dan menghafalkan dalil al-Qur'an dan hadis agar disangka orang ia itu alim, wara', shalih, mendapatkan kemegahan, pujian, kebesaran, kemuliaan, dan sebagainya. Ini riya orang yang ahli agama, sementara riya ahli dunya adalah dengan cara membalikkan ucapan di dalam syair, membicarakan yang aneh-aneh, menampakkan ungkapan aneh supaya hati manusia cenderung kepadanya, dan sebagainya.

${ }^{21}$ Riya pada aspek asal amal seperti melanjutkan berdiri di dalam salat, melambatkan ruku' dan sujud, menundukkan kepala di dalam berdiri ketika salat, meninggalkan berpaling di dalam salat, dan sebagainya supaya ia dipuji orang, agar orang menyebutnya sebagai orang shalih, dan sebagainya, serta demikian juga riya dengan berpuasa, haji, bersedeqah, berbuat jemuan yang semua itu supaya ia dipuji oleh orang, mendapat kemegahan, harta, dan sebagainya.

${ }^{22}$ Riya dari aspek membanyakkan murid dan sahabat yang mengikutinya, seperti suka dikunjungi oleh orang-orang besar dan raja-raja. Lihat alPalimbani, Siyar..., 148-9. 
dengan para ulama. Maka barangsiapa yang melakukannya di antara kalian, nerakalah tempatnya."

Tujuan-tujuan belajar yang dirumuskan al-Māwardi di atas tidak hanya dilihat dalam ranah kognitif, afektif, dan psikomotorik, tapi juga dalam ranah iman. Artinya, belajar itu bukan semata-mata bertujuan mengisi otak dengan berbagai macam ilmu pengetahuan, memfungsikan, dan mengaplikasikan ilmu, tapi juga meningkatkan kualitas keimanan (spiritual). Jadi, dalam pencapaian tujuan belajar, al-Māwardi nampaknya menyeimbangkan antara domain ilmu, akhlaq, amal, dan iman.

Tujuan-tujuan belajar yang dirumuskan al-Māwardi di atas secara umum dapat diklasifikasikan kepada dua macam, yaitu tujuan ukhrawi dan duniawi. Tujuan ukhrawi disebut juga dengan tujuan akhir atau tujuan primer, sementara tujuan duniawi disebut tujuan sementara atau perantara, artinya perantara untuk mencapai tujuan akhir.

\section{Deskripsi Teori al-Māwardi tentang Indikator Keberhasilan Belajar}

Kesuksesan belajar merupakan tujuan yang ingin dicapai oleh setiap anak didik. Untuk mengetahui sukses tidaknya belajar anak didik, perlu memperhatikan indikator-indikatornya. Mengenai indikator kesuksesan belajar anak didik, al-Māwardi mengatakan:

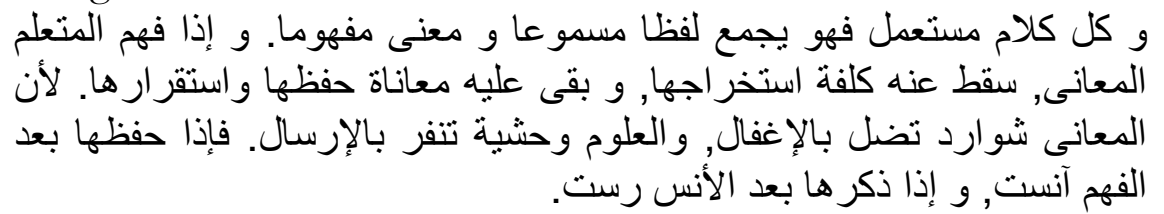

Artinya: Setiap perkataan yang diucapkan mengandung lafadh yang didengar dan makna yang dipahami. Bila pelajar memahami makna tersebut, maka akan mengetahui maksudnya, membantunya untuk menghafal dan tetap melekat dalam otaknya, karena makna-makna itu akan menghilang karena mengabaikannya dan ilmu akan menjadi liar karena lepas dari ingatan. Bila ilmu dihafal setelah dipahami maka ilmu itu akan jinak, dan bila ilmu itu diingat-ingat kembali setelah dijinakkan, maka ilmu itu akan berlabuh atau tertambat dalam otak.

Sa’̄id Ismā’il al-Qādi mengomentari ungkapan al-Māwardi di atas dengan mengatakan bahwa al-Māwardi menginginkan anak didik tidak hanya menghafal ilmu pengetahuan saja dan tidak 
menjadikan akalnya sebagai alat mencari ilmu pengetahuan, melainkan harus memahami dan mengetahui tujuan ilmu pengetahuan tersebut. ${ }^{23}$ Dengan kata lain, anak didik yang memahami ilmu pengetahuan akan membantunya untuk menghafal dan mengingatnya di samping mengetahui hakikat dan maksudnya. ${ }^{24}$

Dengan demikian dapat disimpulkan bahwa menurut penjelasan al-Mawardi di atas, sekurang-kurangnya ada empat indikator keberhasilan belajar anak didik, yaitu: 1) menghafal, 2) memahami, 3) mengetahui tujuan belajar, dan 4) mengamalkan ilmu.

\section{Menghafal (al-hif:)}

Menghafal adalah "berusaha meresapkan ke dalam pikiran agar selalu ingat." 25 Menurut al-Māwardi, menghafal merupakan salah satu indikator keberhasilan belajar yang sangat penting. Hal ini karena menghafal akan membantu kesuksesan anak didik dalam penguasaan ilmu pengetahuan. Meskipun menghafal akan membantu kesuksesan anak didik dalam belajar, tapi menghafal berada pada tingkat rendah dalam penguasaan ilmu pengetahuan karena menghafal hanya sekedar mengetahui sesuatu.

\section{Memahami (al-fahm)}

Memahami atau comprehend adalah upaya yang dilakukan untuk menguasai sesuatu dengan pikiran. ${ }^{26}$ Belajar menurut alMāwardi tidak cukup dengan menghafal apa yang diperlukan, melainkan harus mengerti atau memahami makna atau maksud filosofis yang dikehendaki dari apa yang dipelajari itu. Menghafal suatu konsep atau simbol tanpa memahami maksudnya dalam pandangan al-Māwardi belum mencapai keberhasilan belajar yang sempurna.

\section{Mengetahui tujuan belajar (al-wuquf'alā gard al-ta'allum)}

Sama dengan aktivitas lain, belajar juga mempunyai tujuan yang diharapkan. Tujuan belajar versi al-Māwardi adalah tujuan

\footnotetext{
23al-Qādi, Usūl.., 272.

${ }^{24}$ Ibid.

${ }^{25}$ Kamisa, Kamus..., 214.

${ }^{26}$ Sardiman, Interaksi..., 42-3.
} 
belajar yang positif (baik). Karena itu, setiap siswa harus mengetahui untuk apa ia belajar, sehingga benar-benar bermanfaat bagi dirinya dan orang lain.

\section{Mengamalkan ilmu (al-'amal bi al-ilm)}

Dalam pandangan al-Māwardi, ilmu tidak hanya semata-mata untuk diketahui, tapi yang paling penting adalah pengamalan (aplikasi) dari apa yang diketahui itu. Pengaplikasian ilmu merupakan tuntutan yang harus dilaksanakan oleh anak didik, karena ilmunya akan bertambah dan lebih bermanfaat bagi dirinya dan orang lain.

Keempat indikator keberhasilan belajar anak didik menurut al-Māwardi di atas dapat diklasifikasikan kepada indikator keberhasilan belajar anak didik dari aspek kognitif, afektif, dan psikomotorik. Sebenarnya ada satu aspek lagi yang sangat menentukan indikator keberhasilan anak didik, yaitu aspek iman. Meskipun al-Māwardi tidak menjelaskannya secara lebih konkret, tapi aspek iman tersebut sangat penting, karena apa pun perbuatan baik yang dilakukan termasuk belajar harus menghubungkan kepada Sang Khalik.

\section{Relevansi Tujuan dan Indikator Keberhasilan Belajar al- Māwardi dengan Konteks Kekinian}

\section{Relevansi Tujuan Belajar}

Relevansi mempunyai arti kaitan atau hubungan, maksudnya hubungan antara sesuatu dengan sesuatu yang lain. ${ }^{27}$ Dalam bagian ini, maksud relevansi adalah kaitan atau kesesuaian pemikiran pendidikan al-Māwardi yang hidup pada era lampau tentang tujuan dan indikator kesuksesan belajar siswa untuk diaplikasikan pada masa kekinian.

Bila diperhatikan kedua tujuan belajar menurut al-Māwardi di atas, maka dapat dikatakan bahwa kedua rumusannya bercorak teosentris. Artinya, tujuan belajar dimaksud dihubungkan langsung dengan Tuhan sebagai tujuan tertinggi dalam menjalankan aktivitas belajar. Kedua tujuan belajar yang

${ }^{27}$ Departemen Pendidikan dan Kebudayaan, Kamus Besar Bahasa Indonesia, (Jakarta: Depdikbud, t.t.), 738. 
bercorak teosentris itu bukan hanya untuk tujuan ukhrawi saja, tapi juga mencakup tujuan duniawi dan ukhrawi sekaligus. Alasannya karena tujuan ukhrawi tidak akan diperoleh tanpa tujuan duniawi.

Tidak sedikit ayat al-Qur'an yang dapat diinterpretasikan sebagai masdar (sumber) utama rujukan tentang tujuan belajar yang menyeimbangkan antara orientasi duniawi dan ukhrawi. Di antara ayat al-Qur'an tersebut, artinya: "Di antara mereka ada yang berdoa, Ya Tuhan kami, berilah kami kebaikan di dunia dan kebaikan di akhirat dan jagalah kami dari siksaan api neraka."28 (Qs. al-Baqarah: 201). "Dan carilah (pahala) negeri akhirat dengan apa yang telah dianugerahkan Allah Swt. kepadamu, tetapi janganlah kamu lupakan bahagianmu di dunia ...."29 (Qs. al-Qașas: 77). Selain itu ada juga hadits-hadits yang dapat dijadikan pijakan berkenaan dengan rumusan tujuan belajar secara seimbang, di antaranya Rasulullah Saw. bersabda, artinya: "Orang yang terbaik di antara kamu adalah yang tidak meninggalkan akhiratnya untuk dunianya dan tidak meninggalkan dunianya untuk akhiratnya dan tidak menjadikan beban bagi orang lain."

Demikian juga halnya dengan tujuan belajar. Bila tujuan belajar dirumuskan untuk tujuan ukhrawi semata, memarginalkan tujuan duniawi sebagai sarana menuju tujuan ukhrawi, maka pendidikan Islam akan berada pada posisi takhalluf/taakhkhur (ketertinggalan/kemunduran). Ini sesuai dengan apa yang dikutip Syamsul Ma'arif dari kritikan-kritikan yang sering diajukan oleh para pemikir pendidikan Islam, dimana salah satu sebab pendidikan Islam masih sangat jauh tertinggal dengan Barat, karena "pendidikan Islam masih berorientasi atau menitikberatkan pada pembentukan 'abd atau hamba Allah. Akhirat di sini, tentu saja adalah segala-galanya, sementara urusan-urusan dunia belakangan." 30 31.

${ }^{28}$ Al-Qur'an dan Terjemahannya (Kuala Lumpur: Pustaka Darul Iman, t.t.),

${ }^{29}$ Ibid., 394.

${ }^{30}$ Syamsul Ma'arif, Revitalisasi Pendidikan Islam, (Yogyakarta: Grahayu Ilmu, 2007), 2. 
Tujuan belajar yang bercorak teosentris yang berorientasi pada tujuan keduniaan dan keakhiratan (dunyäwiyyah dan ukhrawiyyah teosentris oriented) secara seimbang hanya berlangsung pada era keemasan Islam. Hal ini dapat diketahui dari keseimbangan antara ilmu-ilmu agama dan ilmu-ilmu dunia pada era tersebut. Pada era kemunduran Islam keseimbangan ini tidak ada lagi (hilang). ${ }^{31}$ Dengan demikian, dapat dipastikan bahwa tujuan belajar yang dirumuskan al-Māwardi seperti itu karena dipengaruhi oleh kondisi lingkungan kehidupan al-Māwardi pada era keemasan pendidikan Islam.

Untuk mencapai kemajuan seperti yang telah dialami umat Islam pada masa lalu, tujuan belajar dalam pendidikan Islam pada era globalisasi dan teknologi ini harus diformat ke arah dunyawiyyah dan ukhrawiyyah teosentris oriented. Kalau tidak, maka tujuan belajar akan selamanya berorientasi pada keduniawian atau keakhiratan semata. Hal ini seperti yang dialami oleh pendidikan dewasa ini, bahwa proses pendidikan atau tujuan belajar masih bercorak material oriented. "Banyak orang yang berkecimpung dalam dunia pendidikan hanya untuk memperoleh keuntungan materi dan banyak juga yang lengah bahwa pendidikan sebenarnya tidak bersasaran agar manusia menumpuk harta, tapi agar manusia lebih manusiawi." 32

Sebenarnya tidak salah menancapkan tujuan belajar karena ingin mendapatkan kebahagiaan duniawi tersebut. Tapi yang salah dan sangat keliru adalah menempatkan tujuan belajar karena Allah Swt. bukan pada posisi pertama dan utama.

Dengan demikian, menurut penulis, kedua rumusan tujuan belajar menurut al-Māwardi tersebut masih sangat relevan untuk dijadikan sebagai tujuan belajar dalam proses pendidikan masa kini, baik di lembaga formal, informal, maupun non formal. Hal ini karena kedua tujuan belajar tersebut dapat membangun pribadi muslim yang ikhlas karena Allah Swt. dalam menjalankan segala bentuk aktivitas baik secara fardi (individual) maupun jamäi (kolektif), dan dapat mengikis dan menjauhi pribadi

${ }^{31}$ Hasan Langgulung, Asas-Asas Pendidikan Islam (Jakarta: Pustaka AlHusna Baru, 2003), 114.

32Abidin Ibnu Rusn, Pemikiran Al-Ghazali tentang Pendidikan, (Yogyakarta: Pustaka Pelajar, 2009), 125. 
muslim dari pola pikir dan gaya hidup materialistik, individualistik, dan kemewahan.

\section{Relevansi Indikator Keberhasilan Belajar}

Keempat indikator keberhasilan belajar siswa menurut alMāwardi di atas bila dilihat secara konkrit akan terlihat persamaan dan perbedaan dengan domain keberhasilan belajar yang dikemukakan oleh Bloom, yang disebut dengan taxonomi Bloom. Perbedaannya dengan Bloom, al-Māwardi tidak menjelaskan doman-domain itu secara rinci dan indikator keberhasilan belajar menurut al-Māwardi tersebut tidak hanya mencakup domain kognitif, afektif, dan psikomotorik, tapi juga meliputi domain iman. Adanya tambahan domain iman ini karena indikator keberhasilan belajar yang diinginkan al-Māwardi harus dikaitkan dengan Sang Pencipta sebagai tujuan terakhir dalam belajar.

Iman, tidak hanya diyakini dalam hati dan diucapkan dengan lidah, tapi juga dimanifestasikan dalam perbuatan. Dengan demikian, bukti seseorang itu beriman diukur dari amalannya. Iman itu terwujud dalam perilaku yang proaktif dan dinamik dalam kehidupan sehari-hari, mulai dari hal-hal yang kecil sampai kepada hal-hal yang besar. Aspek iman inilah yang membedakan indikator keberhasilan belajar al-Mawardi dengan indikator keberhasilan belajar menurut taxonomi Bloom. Bloom tidak mementingkan akan pentingnya agama dan keimanan dalam pendidikan. Sementara pendidikan Islam menurut al-Māwardi mengutamakan peningkatam kualitas iman. ${ }^{33}$

Pada dasarnya paradigma pendidikan yang ditawarkan alMāwardi lebih mengacu kepada aspek moral-transendental (afektif) meskipun juga tidak mengabaikan aspek kognitif (sensual-logis) dan psikomotorik (sensual-empiris). Hal ini relevan dengan aspirasi pendidikan Islami, yakni aspirasi yang bernafaskan moral dan agama. Karena dalam taksonomi pendidikan Islami, dikenal adanya aspek transendental, yaitu domain iman disamping tiga domain, kognitif, afektif, dan

${ }^{33}$ Abd. Rachman Assegaf, Filsafat Pendidikan Islam; Paradigma Baru Pendidikan Hadhari Berbasis Integratif-Interkonektif (Jakarta: RajaGrafindo Persada, 2011), 95. 
psikomotorik yang dikembangkan B.S. Bloom dkk. ${ }^{34}$ Domain iman merupakan titik sentral yang hendak menentukan sikap dan nilai hidup peserta didik, dan dengannya pula menentukan nilai yang dimiliki dan amal yang dilakukan.

Dalam pelaksanaan pendidikan dewasa ini, indikator keberhasilan belajar anak didik di semua jenjang atau unit pendidikan berpedoman kepada domain/ranah yang dikemukakan oleh Bloom. Meskipun dari satu aspek ranah Bloom ini memberi kontribusi dalam bidang pendidikan, tapi dari aspek lain memiliki kekurangan. Barangkali untuk menutupi kekurangan indikator keberhasilan belajar anak didik yang dikemukakan Bloom itu, domain/ranah iman yang dikemukakan oleh al-Mawardi perlu dipedomani sebagai tambahan karena ranah iman sangat penting untuk mengukur sejauh mana keberhasilan anak didik dalam belajar.

Islam adalah agama tauhid. Karena itu belajar dan indikator keberhasilan siswa dalam belajar juga harus memiliki dimensi tauhid, yaitu dimensi dialektika horizontal dan ketundukan vertikal. Belajar dalam Islam dalam dimensi dialektika horizontal sama dengan belajar pada umumnya, yang tak terpisahkan dengan pengembangan ilmu pengetahuan dan teknologi (iptek). Sedangkan belajar dalam Islam dalam dimensi ketundukan vertikal adalah kepatuhan, ketaatan, dan taqarrub kepada Allah Swt. Ini mengindikasikan bahwa pendidikan qalbu sangat dituntut agar membawa manfaat yang besar bagi umat manusia. ${ }^{35}$

Dengan demikian dapat disimpulkan bahwa indikator keberhasilan belajar anak didik menurut al-Māwardi yang mencakup aspek kognitif, afektif, psikomotor, dan iman masih sangat relevan untuk diaplikasikan dalam rangka mengetahui indikator keberhasikan anak didik dalam pendidikan di berbagaibagai tingkat/unit pendidikan, khususnya pendidikan Islam,

${ }^{34}$ Muhaimain, 1991, Konsepsi Pendidikan Islam, Sebuah Telaah Komponen Dasar Kurikulum, (Solo: Ramadani), 72-3.

35Jumberansyah Indar, "Konsep Belajar Menurut Pandangan Islam," ULUL ALBAB: Jurnal Studi Islam, Sains dan Teknologi, Vol. 3 Nomor 2 Tahun 2001, 35. 
mulai dari jenjang pendidikan rendah sampai jenjang pendidikan yang paling tinggi.

\section{Catatan Akhir}

Al-Māwardi adalah salah seorang tokoh pendidikan Islam yang mempunyai kontribusi penting dalam dunia pendidikan, khususnya dalam aspek tujuan dan indikator keberhasilan belajar siswa.

Tujuan belajar menurut al-Māwardi secara umum dapat diklasifikasikan kepada dua, yaitu tujuan yang baik (positif) dan tujuan yang jelek (negatif). Al-Māwardi memformulasikan tujuan belajar yang baik (positif) kepada dua aspek, yaitu (1) qāsidan wajh al-Lah Ta'älā (niat karena Allah Swt.) dan (2) wäthiqan bi taysìr alLah bi niyyat al-khälisah wa 'azimah sädiqah (mencari kemudahan dari Allah Swt. dengan niat suci dan cita-cita yang mulia). Sedangkan tujuan belajar yang jelek (negatif) diformulasikan alMāwardi kepada tiga aspek, yaitu (1) tujuan belajar karena riya, (2) dipuji oleh orang-orang bodoh, dan (3) berdebat dengan para ulama. Selanjutnya tujuan-tujuan belajar yang dirumuskan alMāwardi di atas secara umum dapat diklasifikasikan kepada dua macam, yaitu tujuan ukhrawi dan duniawi.

Kedua rumusan tujuan belajar menurut al-Māwardi tersebut masih sangat relevan untuk dijadikan sebagai tujuan belajar dalam proses pendidikan masa kini, baik di lembaga formal, informal, maupun non formal. Hal ini karena kedua tujuan belajar tersebut dapat membangun pribadi muslim yang ikhlas karena Allah Swt. dalam menjalankan segala bentuk aktivitas baik secara fardi (individual) maupun jamä’i (kolektif), dan dapat mengikis dan menjauhi pribadi muslim dari pola pikir dan gaya hidup materialistik, individualistik, dan kemewahan. Relevansinya dari aspek lain adalah adanya keseimbangan antara tujuan duniawi dengan ukhrawi dimana keduanya saling melengkapi dan tidak bisa dipisahkan antara satu dengan lainnya. Pendidikan Islam yang tujuannya dirancang dengan tujuan duniawi dengan ukhrawi yang seimbang akan mampu menghadapi tantangan modernitas, globalisasi, dekadensi moral, dan sebagainya. 
Ada empat indikator keberhasilan belajar anak didik menurut al-Māwardi, yaitu: 1) menghafal, 2) memahami, 3) mengetahui tujuan belajar, dan 4) mengamalkan ilmu. Keempat indikator keberhasilan belajar anak didik menurut al-Māwardi di atas dapat diklasifikasikan kepada indikator keberhasilan belajar anak didik dari ranah kognitif, afektif, dan psikomotorik. Ranahranah tersebut nampaknya memiliki kekurangan jika tidak dilengkapi dengan ranah iman, meskipun ranah iman ini tidak dijelaskan secara konkret oleh al-Māwardi.

Gagasan-gagasan al-Māwardi tentang pendidikan perlu dikaji kembali secara lebih luas dan mendalam sehingga dapat diadopsi dalam mengambil dan merumuskan kebijakan-kebijakan pendidikan. Tujuan dan indikator keberhasilan belajar anak didik yang digagasnya perlu dijadikan rujukan, dan diaplikasikan dalam dunia pendidikan masa kini di semua jenjang pendidikan, terutama jenjang pendidikan Islam formal untuk pengembangan pendidikan Islam kekinian. Wa al-Lāh a lam bi al-sawāb.

\section{Daftar Pustaka}

Ahmad, Jamil. 1996. Seratus Muslim Terkemuka, ter. Tim Penerjemah Pustaka Firdaus. Jakarta: Pustaka Firdaus.

Assegaf, Abd. Rachman. 2011. Filsafat Pendidikan Islam; Paradigma

Baru Pendidikan Hadhari Berbasis Integratif-Interkonektif. Jakarta:

RajaGrafindo Persada.

A.M., Sardiman. 2004. Interaksi dan Motivasi Belajar Mengajar. Jakarta: RajaGrafindo Persada.

Departemen Pendidikan dan Kebudayaan. Kamus Besar Bahasa Indonesia. Jakarta: Depdikbud.

Eliade, Mircea. The Encyclopedia of Religion, vol. 9, New York: Macmillan Publishing Company.

al-Harmany, Yaqūt. Mu'jam al-Udabā'. Jilid XV. Dār al-Ihyā’ alTurāth al- 'Arabi.

Ibnu Rusn, Abidin. 2009. Pemikiran Al-Ghazali tentang Pendidikan. Yogyakarta: Pustaka Pelajar.

Indar, Jumberansyah. "Konsep Belajar Menurut Pandangan Islam", ULUL ALBAB Jurnal Studi Islam, Sains dan Teknologi. vol. 3 nomor 2 (2001). 
Kamisa, 1997. Kamus Lengkap Bahasa Indonesia Dilengkapi: Ejaan Yang Disempurnakan dan Kosa Kata Baru. Surabaya: Kartika.

Kathīr, Ibnu. al-Bidāyah wa al-Nihāyah, jilid 12, al-Qāhirah: Dār al-Fikr al-'Arabi.

Langgulung, Hasan. 2003. Asas-Asas Pendidikan Islam. Jakarta: Pustaka Al-Husna Baru.

Ma'arif, Syamsul. 2007. Revitalisasi Pendidikan Islam. Yogyakarta: Grahayu Ilmu.

al-Māwardiy, Abū al-Hasan 'Ali bin Muhammad bin Habīb alBasriy. 1990. Adāb al-Dunyā wa al-Dìn. Tab'ah Jadīdah Munaqqahah Musahhahah, Ishāraf maktab al-Buhūth wa alDirāsat. Bairūt-Libnan: Dār al-Fikr li al-Thabāah wa alNashr wa al-Tauzî̀.

Fiqri.

. 1995. al-Adāb al-Dunyà wa al-Dìn. Bayrūt: Dār al

Muhaimain. 1991. Konsepsi Pendidikan Islam, Sebuah Telaah Komponen Dasar Kurikulum. Solo: Ramadani.

Nasution, Harun. 1992. Pembaharuan dalam Islam Sejarah Pemikiran dan Gerakan. Jakarta: Bulan Bintang.

Nata, Abuddin. 2001. Pemikiran Para Tokoh Pendidikan Islam; Seri Kajian Filsafat Pendidikan Islam. Jakarta: RajaGrafindo Persada.

2012. Sejarah Sosial Intelektual Islam dan Institusi Pendidikannya. Jakarta: RajaGrafindo Persada.

al-Palimbani, Abd al-Samad. Siyar al-Sälikin fi Tariqah al-Sadat alSufiyah, juz 3-4. Indonesia: Dār al-Kutub al-'Arabiyah.

al-Qādi, Sa'īd Ismāill. 2002. Usūl al-Tarbiyah al-Islāmiyah, alTab'ah al-Ulā, Al-Qāhirah: 'Ālam al-Kutub.

Al-Sam'āni. 1988. al-Ansab, juz 5, taqdīm wa ta'līq 'Abd Allah 'Umar al-Barudi, Bayrūt: Dār al-Jinan.

al-Zarkali, Khair al-Dīn. 1992. al-A'làm, juz 4, Beirut: Dār al-'Ilm li al-Malāyīn, 1992. 